\title{
Assessment of Magnitude of Sexually Transmitted Infections, Sexual and Reproductive Health Status among Prisoners Aged Between 18-49 Years in Tabor Prison, Hawassa, Ethiopia
}

\section{Sailaja Busi* and Zewdie Oltaye}

School of Nursing and Midwifery, College of Medicine and Health Sciences, Hawassa University, Hawassa, Ethiopia (*sailajabusi@gmail.com).

\begin{abstract}
Lack of access to SRH is a major public health concern, especially in developing countries. The objective of the study is to assess the magnitude of STIs and SRH status among prisoners aged between 18-49 years in Tabor prison, Hawassa, Ethiopia. A descriptive cross sectional study was conducted. Systemic random sampling technique was used and the sample size was 292. The living status of the respondents before detention $\left(\chi^{2}=12.8, \mathrm{p}<0.05\right)$, maternal and paternal education $\left(\chi^{2}=20.6, \mathrm{p}<0.05\right)$, and sexual health information $\left(\chi^{2}=11.9, \mathrm{p}<0.05\right)$, having intercourse with multiple sexual partners $(\mathrm{p}<0.05)$, and STIs before imprisonment $(\mathrm{p}<0.05)$ had shown significant association at $\mathrm{p}<0.05$ and $\mathrm{p}<0.01$. The magnitude of STIs was found as $5.1 \%$ among the respondents and $30(14.5 \%)$ respondents were HIV positive.
\end{abstract}

Keywords: Sexual and reproductive health, Sexually transmitted infections, Prisoners, Hawassa, Ethiopia.

\section{INTRODUCTION}

Sexual and reproductive health (SRH) is important to all human beings, and for the social and economic development of communities and nations. SRH is a state of complete physical, mental and social wellbeing not merely the absence of disease or infirmity in all matters related to reproductive system and to its function. SRH therefore implies people are able to have satisfying and safe sexual life and they have a capability to reproduce and the freedom to decide when and how often to do so (WHO/UNODC/UNAIDS, 2004). Lack of access to SRH is a major public health concern, especially in developing countries. For instance, death and disability caused by SRH accounted for 18 percent of the total disease burden globally in 2001, though there is considerable regional variation (Glasier et al., 2006). Sexually transmitted infections (STIs) are the significant infections of the young mainly because their sexual relations are often unintentional, sometimes as a result of pressure or force, and typically happen before they have the experience and skills to defend themselves (Glasier et al., 2006).

Every year, 30 million people spend time in prisons or other closed settings and more than 10.2 million are incarcerated at any given time. Prisoners live in a high-risk environment for HIV transmission with drug use and needle sharing, tattooing with homemade and unsterile equipment, unsafe sex and rape. Overcrowding as well as stress, malnutrition, drugs, and 
violence weaken the immune system, making people living with HIV more susceptible to getting ill. Yet, prisoner wellbeing is often neglected and overlooked (Walmsley, 2013). Prison is a factor leading to deterioration of health and well-being of prisoners, and becoming breeding grounds for communicable diseases and facilitates unhealthy behavior. Additionally it forms high risk settings because of unprotected sexual relations, prostitution, rapes, and high turnover of populations (Hayton, 2007). Globally, an estimated 9 million people are in prisons per year. Prisoners were the vulnerable group of population often to the sexual and other demands. This population is constantly changing so they are not permanently sealed off from the community (WHO, 2007). A prison is an environment with special difficulty in the promotion of health. Prisoners may tend to have poor physical, mental and social health than the general population because their life style is more likely to put them at risk of several diseases (WHO/UNODC/UNAIDS, 2007a\&b). Prisoners are at high risk for the transmission of STIs in the closed environment of prison. Women prisoners are especially vulnerable to sexual abuse including rape by both male prison staffs and male prisoners (WHO/UNODC/UNAIDS, 2007a\&b). There are countries where women prisoners were held in small facilities adjacent to or within the prison of men. STIs are a major public health problem in prison and their escalating prevalence rate was largely as a result of unprotected sex and, to some extent sharing of contaminated needles. Prison population statistics showed that a large proportion of male prisoners aged 21-39 years were pleasure seekers, since they were more likely to have injection of drugs, have multiple sexual partner and sex with the same sex (Stewart, 2007).

Several studies have shown that sexual activity including rape and other forms of sexual violence occurs in prisons and result in transmission of HIV and other STIs (Barry \& Katie, 2009). A study done in Nepal revealed that $71 \%$ of prisoners were intravenous drug users and $75 \%$ of them always shared needles, $38 \%$ had casual partners and $30 \%$ had frequent visits to sex workers, none of the inmates ever used condoms, and only $14 \%$ perceived that they might have HIV (Herman, 2001). Another study done in India revealed that $76.6 \%$ of the male inmates gave history of penetrative sex, among these $54.2 \%$ gave a history of having multiple sexual partners and the majority had unprotected sex, even with commercial sex workers while $72.5 \%$ of them were not aware of HIV(Anjali, 2014). A study conducted in Nigeria showed that $14.9 \%$ of inmates reported having sexual intercourse in the prison and among these $43.8 \%$ claimed to have used condoms regularly; it is thus seen that prisoners engage in sexual activities right inside prisons during incarceration, although one would think this 
should not be possible because a prisoner's freedom is expected to be limited (Olugbenga et al., 2013).

In Ethiopia, traditional practices and poor living situations often lead young people to engage in sex at an early age. As most of the young adults who enter into a sexual relationship for the first time do not use condom, the unprotected sex exposes the young to STIs. Early sexual debut, the practice of having multiple sexual partners, and limited use of condoms were the major risk factors for the spread of STIs among this population (Zhuzhi et al., 2008).

\section{METHODOLOGY}

A descriptive cross sectional study was conducted in Tabor sub-city, Hawassa, southern part of Ethiopia. Systemic random sampling technique was used and the sample size was determined by using single proportion formula with the following assumptions: prevalence of STIs $=0.26$, degree of precision $=5 \%$, level of confidence $=95 \%(\mathrm{z}=1.96)$, and the final sample size was 292. The response rate was $99 \%$. A self-administered structured questionnaire was administered to the subjects. The questionnaire enquires the socio-demographic data, prison conditions, use of substances, sexual and reproductive health behaviors, self-reported symptoms of STIs, general health status of the respondents and factors associated with STI symptoms. The questionnaire was tested for its reliability, consistency, and validity.

\subsection{Ethical Clearance}

Ethical clearance was obtained from Institutional Review Board, Hawassa University. Formal permissions were obtained from the concerned authorities of the prison. No materials were used during the study. Source of funding is not applicable.

\section{RESULTS}

\subsection{Socio-demographic Variables of Respondents}

The characteristics of the sample by gender showed that male prisoners were $233(80 \%)$, females were $58(20 \%)$. More respondents, $32 \%$ and $31 \%$ were found in two age groups, 1824 and 25-29 years respectively and the rest age categories were 30-34 years (18\%), 35-39 years $(7.8 \%)$, 40-44years ( 6\%) and 45-49 years (5.2\%). Followers of Protestant religion were $47.7 \%$ of the respondents and the Orthodox were $38.8 \%$. The predominant ethnic group was of Sidama $113(38.8 \%) .88$ respondents $(30.3 \%)$ had education above $12^{\text {th }}$ grade and 80 (27.5\%) had secondary school education. $214(79.3 \%)$ of prisoners have a plan to continue school after they are released from prison. The marital status of the respondents showed that 
most of them $153(52.6 \%)$ were not married followed by $106(36.4 \%)$ were married respondents. Before imprisonment, 109 (37.4\%) respondents were living with their parents, $89(30.6 \%)$ were living with their spouses and 50 (17.2\%) were living alone. Before imprisonment, $84(28.9 \%)$ respondents were students, 59 (20\%) were daily labors and small traders, 53 (18.2\%) were Government employed.

\subsection{Respondent's Situation in Prison}

Most of the surveyed participants, 247 (84.9\%), had never been in prison before, $31(10.6 \%)$ of the prisoners had one time previous experience of imprisonment and the rest $13(4.5 \%)$ had twice or more times of the prison experience. A greater percentage of prisoners 114 (39.2\%) stayed in the current prison between the range of 11-20 months, $80(27.5 \%)$ stayed between 2-10 months, and $77(26.5 \%)$ stayed between the range of 21 months up to 10 years of duration. $143(49.1 \%)$ participants were living in a room which consists of more than 100 prisoners, and 93 (32\%) prisoners were living in a room that consists of 81-100 prisoners. $248(85.2 \%)$ spend time outside, their prison room during the day time and the other 23 (7.9\%), and $20(6.9 \%)$ ) spend time outside the room twice and once a day respectively. The sleeping situation of the respondents showed that over half of the respondents, 195 (67\%), were sleeping on mattress with other inmates on floor, 59 (20.3\%) were sleeping alone on bed or mattress on floor, and $37(12.7 \%)$ were sleeping on bed with inmates. Majority of the respondents, 104 (35.7\%), reported that they never had family support, 49 (16.8\%) respondents' family members were supporting by providing foods, and parents of $63(21.3 \%)$ were providing both support and food.

\subsection{Substance Usage Habits of the Respondents in Prison}

From total of 291 respondents, 61 (21\%) were the habitual users of substances like alcohol, khat and cigarettes. Among the 61 respondents, 55 (18.9\%) were using alcohol, 40 (13.7\%) were smoking cigarettes and $52(17.9 \%)$ were chewing khat (locally known as chat). 60 (20.9\%) respondents answered that it is possible to use substances in prison. Among those 61 habitual users of substances, 23 (41.8\%) drink alcohol once per week, 20 (36.4\%) drink every day and 6 (10.9\%) drink twice per week, 17 (42.5\%) smoke three times per day, $11(27.5 \%)$ smoke more than three times a day, and $6(15 \%)$ smoke once a day and $6(15 \%)$ smoke twice a day, $42.3 \%$ chew khat every day, $28.8 \%$ chew once per week, $17.4 \%$ chew twice per week.

\subsection{Sexual and Reproductive Health Behaviors of Prisoners}

Among 292 studied sample, 214 (73.2\%) respondents were sexually active; 274 (81.3\%) had experienced premarital sex; $142(66.4 \%)$ had their first sexual intercourse at the age group of $17-24$ years, $46(21.5 \%)$ had it before the age of 16 years, $23(10.7 \%)$ had it at the age group 
of $25-30$ years, and $3(1.4 \%)$ had it after the age of 30 years. Median age at first sex was $17 \pm 2.5$ years. $99(46.5 \%)$ of the respondents had multiple sexual partners, 67 (31.5\%) of male prisoners gave a history of sex with commercial sex workers, and 20 (9.3\%) had history of STIs. Among 214 sexually active respondents, 210 (98.1\%) inmates identified themselves as heterosexual before detention. Among 13 respondents who had consensual sex in prison, 10 (76.9\%) considered themselves as heterosexual and 3 (23.1\%) as homosexuals. Among 214 sexually active respondents, more than half of the respondents $(55.1 \%)$ didn't use condom consistently before imprisonment. 8 (73\%) of the 11 respondents had the symptoms of STIs once during their stay in the prison and 9 (81.9\%) of the 11 respondents reported STI symptoms and received treatment.

\subsection{Self-reported Symptoms of STIs among Respondents}

Among 292 respondents, 20 (6.8\%) reported STI symptoms before incarceration, and 11 (3.8\%) reported the symptoms in prison. All of those 11 respondents who reported the STI symptoms in prison had history of burning sensation during urination and sore penis except one female respondent (9\%) who had sore vagina; 10 of those 11 respondents (91\%) reported abnormal genital discharge; 5 (45.4\%) had pain during or after sexual intercourse; and 8 (72\%) reported more than one symptom. The one female respondent had experienced white vaginal discharge, bleeding or blood spotting from the vagina, thick, cloudy or strong vaginal odor discharge from vagina, vaginal itching or irritation, and abnormal menstrual bleeding.

\subsection{General sexual and reproductive health of respondents}

Among the 291 respondents, 14 (4.6\%) answered it is possible to have sex in prison by legal ways. $76(26.1 \%)$ respondents had sexual and reproductive health checkups in prison; of those, $50 \%$ had checkups more than two times, $22.4 \%$ had twice, and $27.6 \%$ once per year. In this study, 51.5\% respondents said prison had no effect on SRH, 25.5\% respondents said it had both positive and negative effects, $14.4 \%$ said prison has negative effect and only $8.6 \%$ said prison had positive effect on sexual and reproductive health. 206 (70.8\%) respondents had HIV test. 135 (65.5\%) were tested before three months of this study and 30 (14.5\%) were found HIV positive.

\subsection{Factors Associated with STI Symptoms of Respondents}

In Chi-square association, living status of the respondents before detention, maternal and paternal education, sexual health information, having intercourse with multiple sexual partners, and STIs before imprisonment had shown significant association at $\mathrm{p}<0.05$ and $\mathrm{p}<0.01$ (Table 1). 
Table 1. Association of factors with symptoms of STIs among respondents in Tabor prison, Hawassa, $2014(\mathrm{~N}=292)$.

\begin{tabular}{|c|c|c|c|c|c|c|c|c|}
\hline \multicolumn{2}{|c|}{$\begin{array}{l}\text { Independent variable } \\
\text { Variable }\end{array}$} & \multicolumn{4}{|c|}{$\begin{array}{l}\text { Dependent variable } \\
\text { (STI in prison) }\end{array}$} & \multirow[t]{3}{*}{$\chi^{2} c a l$} & \multirow[t]{3}{*}{$\begin{array}{l}\text { P } \\
\text { Value }\end{array}$} & \multirow[t]{3}{*}{$\begin{array}{l}\text { Signifi- } \\
\text { cance }\end{array}$} \\
\hline & & \multicolumn{2}{|c|}{ Yes } & \multicolumn{2}{|l|}{ No } & & & \\
\hline & & $\begin{array}{l}\text { Freq- } \\
\text { uency }\end{array}$ & $\%$ & $\begin{array}{l}\text { Freq- } \\
\text { uency }\end{array}$ & $\%$ & & & \\
\hline \multirow{2}{*}{ Sex } & Male & 10 & 4.67 & 163 & 76.2 & \multirow[t]{2}{*}{0.75} & \multirow{2}{*}{$\begin{array}{l}P>0.1 \\
d f=1\end{array}$} & \multirow[t]{2}{*}{ NS } \\
\hline & Female & 1 & 0.46 & 40 & 18.69 & & & \\
\hline \multirow[t]{5}{*}{ Age in years } & $18-24$ & 2 & 0.93 & 51 & 23.83 & \multirow[t]{5}{*}{4.24} & \multirow{5}{*}{$\begin{array}{l}\mathrm{P}>0.1 \\
\mathrm{df}=4\end{array}$} & \multirow[t]{5}{*}{ NS } \\
\hline & $25-29$ & 2 & 0.93 & 76 & 35.5 & & & \\
\hline & $30-34$ & 3 & 1.4 & 42 & 19.6 & & & \\
\hline & $35-39$ & 3 & 1.4 & 21 & 9.8 & & & \\
\hline & $40-44$ & 1 & 0.5 & 13 & 6.07 & & & \\
\hline \multirow{2}{*}{ Marital status } & Married & 5 & 2.3 & 100 & 46.7 & \multirow{2}{*}{0.06} & \multirow{2}{*}{$\begin{array}{l}\mathrm{P}>0.1 \\
\mathrm{df}=1\end{array}$} & \multirow[t]{2}{*}{ NS } \\
\hline & Unmarried & 6 & 2.8 & 103 & 48.2 & & & \\
\hline \multirow{3}{*}{$\begin{array}{l}\text { Before } \\
\text { detention } \\
\text { living with }\end{array}$} & Alone & 3 & 1.4 & 56 & 2.3 & \multirow[t]{3}{*}{12.8} & \multirow{3}{*}{$\begin{array}{l}\mathrm{P}<0.005 \\
\mathrm{df}=2\end{array}$} & \multirow[t]{3}{*}{$\mathrm{S}$} \\
\hline & Relative & 2 & 0.9 & 3 & 1.4 & & & \\
\hline & Wife husband & 6 & 2.8 & 142 & 66.4 & & & \\
\hline \multirow{3}{*}{$\begin{array}{l}\text { Job before } \\
\text { detention }\end{array}$} & Unemployed & 4 & 1.87 & 38 & 17.76 & \multirow[t]{3}{*}{0.75} & $\mathrm{P}>0.1$ & NS \\
\hline & $\begin{array}{l}\text { Government } \\
\text { employ }\end{array}$ & 4 & 1.87 & 49 & 22.89 & & $\mathrm{df}=2$ & \\
\hline & Daily labor & 3 & 1.4 & 56 & 26.2 & & & \\
\hline Paternal & Formal & 4 & 1.87 & 177 & 82.7 & 20.6 & $\mathrm{P}<0.05$ & $\mathrm{~S}$ \\
\hline education & No formal & 7 & 3.27 & 26 & 12.1 & & $\mathrm{df}=1$ & \\
\hline Maternal & Formal & 6 & 2.8 & 70 & 32.7 & 1.8 & $p>0.1$ & $\mathrm{NS}$ \\
\hline education & No formal & 5 & $2 / 33$ & 133 & 62.15 & & $\mathrm{df}=1$ & \\
\hline $\begin{array}{l}\text { Parent work } \\
\text { status }\end{array}$ & $\begin{array}{l}\text { both do not } \\
\text { work }\end{array}$ & 6 & 2.8 & 47 & 21,96 & 7.7 & $\begin{array}{l}0.01< \\
\mathrm{p}<0.05\end{array}$ & NS \\
\hline & $\begin{array}{l}\text { Both work out } \\
\text { side }\end{array}$ & 3 & 1.4 & 33 & 15.4 & & $\mathrm{df}=2$ & \\
\hline & $\begin{array}{l}\text { One work out } \\
\text { side }\end{array}$ & 2 & 0.93 & 120 & 56.07 & & & \\
\hline Parent & Poor & 5 & 2.3 & 90 & 42.05 & 2.9 & $\mathrm{p}>0.1$ & \\
\hline economic & Moderate & 5 & 2.3 & 54 & 25.23 & & $\mathrm{df}=2$ & NS \\
\hline status & Rich & 1 & 0.5 & 59 & 27.57 & & & \\
\hline Previous & Yes & 3 & 1.4 & 41 & 19.2 & 0.3 & $p>0.1$ & NS \\
\hline impressments & No & 8 & 3,7 & 162 & 75.7 & & $\mathrm{df}=1$ & \\
\hline Period of & $<10 \mathrm{mo}$ & 4 & 1.9 & 49 & 22.9 & 0.7 & $p>0.1$ & NS \\
\hline & $10-20 \mathrm{mo}$ & 4 & 1.9 & 90 & 42.05 & & & \\
\hline & $>20 \mathrm{mo}$ & 3 & 1.4 & 64 & 29.9 & & & \\
\hline Family & Yes & 6 & 2.8 & 154 & 71.96 & 2.4 & $p>0.1$ & NS \\
\hline support & No & 5 & 2.33 & 49 & 22.9 & & $\mathrm{df}=1$ & \\
\hline Alcohol & Yes & 4 & 1.9 & 30 & 14 & 3.9 & $0.01<$ & \\
\hline & No & 7 & 3.3 & 173 & 80.84 & & $\begin{array}{l}\mathrm{p}<0.05 \\
\mathrm{df}=1\end{array}$ & NS \\
\hline Chat (khat?) & Yes & 6 & 2.8 & 40 & 18.7 & 3.9 & $0.01<$ & NS \\
\hline & No & 5 & 2.33 & 163 & 76.2 & & $\begin{array}{l}\mathrm{p}<0.05 \\
\mathrm{df}=1\end{array}$ & \\
\hline
\end{tabular}




\begin{tabular}{|c|c|c|c|c|c|c|c|c|}
\hline \multirow[t]{2}{*}{ Cigarette } & Yes & 2 & 0.9 & 30 & 14 & \multirow[t]{2}{*}{0.1} & \multirow{2}{*}{$\begin{array}{l}\mathrm{p}>0.1 \\
\mathrm{df}=1\end{array}$} & \multirow[t]{2}{*}{$\mathrm{NS}$} \\
\hline & No & 9 & 4.2 & 173 & 80.84 & & & \\
\hline \multirow{2}{*}{$\begin{array}{l}\text { Development } \\
\text { al and sexual } \\
\text { information }\end{array}$} & Yes & 9 & 4.2 & 163 & 76.2 & \multirow[t]{2}{*}{11.9} & \multirow{2}{*}{$\begin{array}{l}\mathrm{P}<0.05 \\
\mathrm{df}=1\end{array}$} & \multirow[t]{2}{*}{$S$} \\
\hline & No & 2 & 0.9 & 40 & 18.7 & & & \\
\hline \multirow{2}{*}{$\begin{array}{l}\text { Multiple } \\
\text { sexual partner }\end{array}$} & Yes & 9 & 4.2 & 90 & 42.05 & \multirow[t]{2}{*}{5.86} & 0.01 & \multirow[t]{2}{*}{$\mathrm{S}$} \\
\hline & No & 2 & 0.93 & 113 & 52.82 & & $\begin{array}{l}\mathrm{p}<0.05 \\
\mathrm{df}=1\end{array}$ & \\
\hline \multirow{2}{*}{$\begin{array}{l}\text { Sex with } \\
\text { commercial } \\
\text { sex worker }\end{array}$} & Yes & 6 & 2.8 & 61 & 28.5 & \multirow[t]{2}{*}{2.9} & 0.05 & \multirow[t]{2}{*}{ NS } \\
\hline & No & 5 & 2.3 & 142 & 66.3 & & $\begin{array}{l}<\mathrm{p}<0.1 \\
\mathrm{df}=1\end{array}$ & \\
\hline \multirow{2}{*}{$\begin{array}{l}\text { Persistent } \\
\text { condom use }\end{array}$} & Yes & 1 & 0.46 & 95 & 44.3 & \multirow[t]{2}{*}{4.4} & 0.01 & \multirow[t]{2}{*}{ NS } \\
\hline & No & 10 & 4.6 & 108 & 50.64 & & $\begin{array}{l}\mathrm{p}<0.05 \\
\mathrm{df}=1\end{array}$ & \\
\hline \multirow{2}{*}{$\begin{array}{l}\text { STI before } \\
\text { imprisonment }\end{array}$} & Yes & 6 & 2.8 & 12 & 5.6 & \multirow[t]{2}{*}{32.29} & $\mathrm{P}<0.05$ & \multirow[t]{2}{*}{$\mathrm{S}$} \\
\hline & No & 5 & 2.3 & 191 & 89.3 & & $\mathrm{df}=1$ & \\
\hline \multirow{2}{*}{$\begin{array}{l}\text { Sexual } \\
\text { orientation }\end{array}$} & Homo & 1 & 0.5 & 3 & 1.4 & \multirow[t]{2}{*}{3.43} & $0.05<$ & \multirow[t]{2}{*}{ NS } \\
\hline & Hetero & 10 & 4.67 & 200 & 93.45 & & $\begin{array}{l}\mathrm{p}<0.1 \\
\mathrm{df}=1\end{array}$ & \\
\hline
\end{tabular}

\section{DISCUSSION}

The prevalence of sexual activity in prisons is largely unknown and thought to be significantly under reported due to denial, fear of stigma and homophobia as well as the criminalization of same sex conduct (Walmsley, 2013). As this study was tried to found the under reported prevalence of STI's among prisoners and the magnitude was $5.1 \%$ and many factors like use of tobacco, alcohol, khat (chat?) and having regular sexual intercourse with other inmates were identified in this study. Inmate concerns about privacy and fear of stigma. Many inmates do not disclose their high-risk behaviors, such as anal sex or injection drug use, because they fear being stigmatized. Health care providers should keep inmate's health care information confidential, know the public health confidentiality and reporting laws, and inform inmates about them. Evidence shows that if HIV testing and counseling is made readily available on entry to prison and throughout incarceration, there will be a good chance to identify the problem earlier and treat them. This is especially true if HIV test and counseling is part of a comprehensive treatment and care program. Most inmates with HIV become infected in their communities, where they may engage in high-risk behaviors or be unaware of available prevention and treatment resources. Prison and jail administrators must weigh the costs of testing and treatment against other needs and STI's screening and testing can identify inmates with disease before they are released. Early diagnosis and treatment can potentially reduce the level of infection in communities to which inmates return. 


\section{CONCLUSION}

Prisoners in Tabor, Hawassa, were having access to use alcohol and khat in the prison. Such substances are likely to cause unhealthy and risky behaviors related to the general, sexual and reproductive health of the inmates and will lead to several diseases including STIs. $5.1 \%$ of the 214 sexually active inmates were found with STI symptoms in the prison. Therefore, one of the measures by which prison authorities can control the STIs in prison is by preventing the accessibility of the abusive materials to the prisoners. Also, it would be ideal to conduct medical tests for HIV and other STIs and STDs both at the time of entry into prison and release from the prison. If such screening of the inmates is conducted early, the infected inmates and the healthy inmates can be provided with the facilities in the prison appropriately, and thus further spread of the STIs can be controlled.

\section{ACKNOWLEDGEMENTS}

We would like to acknowledge Hawassa University, College of Medicine and Health Sciences, School of Nursing and Midwifery and Prison authorities for giving this opportunity for us which can equip us with the knowledge and skill of research and can help us a lot in our future careers. Finally, our acknowledgment would also extend to our study participants for their involvement and genuine answers.

\section{REFERENCE}

Anjali, B. 2014. Reproductive Health Needs of Adolescent and Adult Prison Inmates. Disha Foundation, Nasik, India, 8p.

Barry, Z \& Katie Kramer, K. 2009. What is the role of prisons and jails in HIV prevention? The Bridging Group, Fact Sheet, 13R, Centre for AIDS Prevention studies and AIDS research institute, University of California, San Francisco, 2p.

Glasier, A., Gülmezoglu, A.M., Schmid, G.P., Moreno, C.G \& Van Look, P.F. 2006.Sexual and reproductive health: a matter of life and death. The Lancet, 368(9547):1595-607.

Hayton, P. 2007. Protecting and promoting health in prisons: a settings approach. In: Lars Møller, HeinoStöver, Ralf Jürgens, Alex Gatherer and Haik Nikogosian (Eds.), Health in prisons: A WHO guide to the essentials in prison health. WHO, EUR/07/5063925 ISBN 97892890 78209, pp15-20. 
Herman, R. 2001. Women in Prison and HIV. Extract from HIV in Prisons: A reader with particular relevance to the newly independent states: World Medical Association. International Committee for Red Cross.Ch-9(193-218), www.icrc.org.159nars.

Olugbenga, B. O., Adeoye, A \& Osagbem, K.G. 2013. Assessment of the Reproductive Health Status of Adult Prison Inmates in Osun State, Nigeria. International Journal of Reproductive Medicine, Hindawi Publications, Article ID: 451460, 2013(2013):9.

Stewart, E. C. 2007. The sexual health and behavior of male prisoners. The Howard Journal; 46 (1):43-59.

Walmsley, R. 2013. World Prison Population List. 11 ${ }^{\text {th }}$ Edition, World Prison Brief, Institute for Criminal Policy Research, International Centre for Prison Studies, Birkbeck, University of London (www.prisonstudies.org,www.icpr.org.uk), 15p.

WHO. 2007. Health in Prison- A guide to the essentials in prison health. Copenhagen, Denmark. EUR/07/5063925, ISBN: 9789289078209.

WHO/UNODC/UNAIDS. 2004. Reproductive health strategy: to accelerate progress towards the attainment to international development goals and targets. World Health Organization, Geneva (www.who.int.reports).

WHO/UNODC/UNAIDS. 2007a. Interventions to Address HIV in Prisons: HIV Care, Treatment and Support. World Health Organization, Geneva (www.who.int.reports).

WHO/UNODC/UNAIDS. 2007b. Interventions to address HIV in prisons: Prevention of sexual transmission. World Health Organization, Geneva (www.who.int.reports).

Zhuzhi, M., Govindasamy, P., DaVanzo, J., Bizuneh, G \& Themme, A. 2008. Trends in Youth Reproductive Health in Ethiopia, 2000 and 2005. Calverton, Maryland: Macro International Inc.110p. 